\title{
TRANSATLANTIC COOPERATION REGARDING CHINA
}

\author{
Zdzisław W. Puślecki*
}

\begin{abstract}
In this research work, author focus on the analysis of the transatlantic cooperation regarding China $P$. $R$. In the recently launched Transatlantic Trade and Investment Partnership (TTIP) negotiations between the USA and the European Union, it has been emphasized that the talks will make reducing regulatory barriers a signature issue. The emphasis on tackling these barriers has generated some excitement, with large figures being offered as estimates of the resulting economic gains. New agreements to remove trade barriers aim at reducing dead-weight costs and at increasing net social gains from international trade. This article examines the problem of regulatory barriers and offers an assessment of what can be achieved. Ideally, the best way to address problems arising from regulatory divergence would be on a multilateral basis also with taking into account the relations among EU and USA with China. The main aim of the paper is to present important problems of transatlantic cooperation regarding China. The particularly objective of the research task are the regulatory trade barriers in USA-EU foreign trade policy, the nature and the promoters of the Transatlantic Trade and Investment Partnership (TTIP), interrelationship between regulatory standards and international cooperation in the TTIP, TTIP impact for China.
\end{abstract}

INTRODUCTION

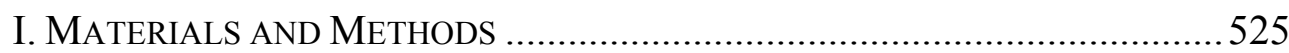

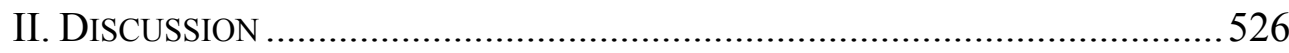

A. The Regulatory Trade Barriers in USA-EU Foreign Trade Policy

B. The Nature and the Promoters of the Transatlantic Trade and Investment Partnership

C. Interrelationship between Regulatory Standards and International Cooperation in the TTIP.....

\footnotetext{
* Professor Dr. Zdzisław W. Puślecki, Full Professor Doctor in Economic Science, Adam Mickiewicz University, Poznań Poland. Faculty of Political Science and Journalism, Department of International Economy, ul.Umultowska 89A 61-614, Poznań Poland. Research fields: The theory of foreign trade policy, the liberalism and protectionism in international trade policy, the transition of Central-Eastern European Countries and their adaptation to the European Union, regional integration and globalisation processes, integration processes in Europe and in the World, knowledge and innovation in economic growth, European Union and China relationship. In the science there are "Puślecki Paradox" and Puślecki classification of non-tariff trade barriers.

Paper prepared in the framework of the Grant OPUS, National Centre of Science-NCS, Nr UMO2013/11/B/HS5/03572, for the $11^{\text {th }}$ Biennial Conference, 2016 ECSA-C, Lord Nelson, Halifax, Nova Scotia, Canada, May 9-11, 2016.
} 


\section{TRANSATLANTIC COOPERATION REGARDING 523}

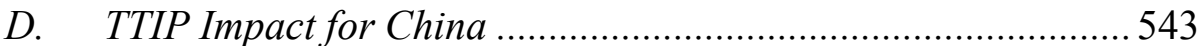

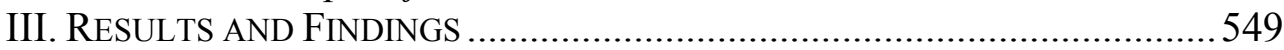

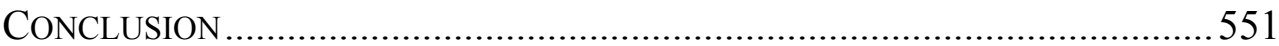

\section{INTRODUCTION}

The United States of America (USA) and European Union (EU) combined account for over $45 \%$ of the world GDP in nominal value and $38 \%$ in terms of purchasing power parity. Foreign direct investment is intense between the two regions and more than a third of the trade consists of intra-company trade, between subsidiaries of companies established both in the EU and in the United States (US).

The US and the EU are heavily invested in each other's market, with nearly \$3.7 trillion in two-way foreign direct investment at year-end 2011 . Meanwhile, US-EU trade in goods and services totals about \$1 trillion annually. However, trade growth has been sluggish in recent years because of the effects of the financial crisis of 2008-2009 and competing subsidy and regulatory policies that impede commercial activity. A new trade accord would remove impediments to bilateral trade and investment. While it would not be a magic potion for prosperity, such reforms would improve the climate for investment and job creation and provide a modest boost to economic growth, since removing even relatively low barriers across a large volume of bilateral trade can have a significant impact.

New agreements to remove trade barriers aim at reducing dead-weight costs and at increasing net social gains from international trade. The World Trade Organization (WTO) was established with the mandate to lower trade barriers among its 159 member countries through rounds of trade negotiations. The WTO's principle of "Most-favoured nation" states that preferred treatment of one country must be extended to all other members of the WTO. However exceptions to this principle are frequent due to the complexity of multilateral negotiation. There are hundreds of regional free trade agreements, sometimes called preferential trade agreements as a reminder that third countries are excluded from the free trade gains.

The project of trade agreement between the US and the EU, at first also known as the Transatlantic Free Trade Area and after the Transatlantic Trade and Investment Partnership began with the 1995 Madrid Agreement on a Transatlantic Agenda, followed by various resolutions and negotiations by and between the US and the EU. In a recent report, the EU-US "high 
level working group on jobs and growth" "1 analyses a range of options far beyond simple tariff removal, including: Elimination of non-tariff barriers to trade in goods, services and investment, enhanced compatibility of regulations and standards and improved cooperation to achieve shared economic goals.

On July 8, 2013, the United States and the European Union launched negotiations on a Transatlantic Trade and Investment Partnership (TTIP). The negotiators aim to deepen what is already the world's largest commercial relationship, thereby "promoting greater growth and supporting more jobs", and to look beyond this particular accord "to contribute to the development of global rules that can strengthen the multilateral trading system." Beyond the important news that the world's two largest economies would be negotiating to liberalize trade, there was also a significant development in terms of the substance of the proposed talks. While past trade negotiations have dealt with domestic regulation as trade barriers in only narrow and limited ways, these talks would make reducing regulatory barriers a signature issue.

Traditional trade barriers, such as tariffs, are relatively low between the two economies, and regulatory barriers are an area that offers great potential economic gain. One widely cited 2009 study suggests some substantial benefits from addressing "non-tariff measures", including regulatory divergence issues, within the context of US-EU trade. After noting that the "total elimination" of such barriers would amount to a $2.5-3.0 \%$ increase in GDP, the study then tried to identify those barriers that are "actionable", that is, ones that could realistically be eliminated. Doing so, the report said, would boost EU GDP by $0.7 \%$ per year, leading to an annual potential gain of $\$ 158$ billion in 2008 dollars; And it would boost US GDP by $0.3 \%$, or $\$ 53$ billion per year.

Different regulations across countries in the same policy area raise costs for businesses and consumers, often without justification. Addressing these differences provides clear gains for efficiency, and benefits for all. Some of the more challenging regulatory issues, where there are strong policy disagreements between the USA and EU, may need to be taken off the table. Furthermore, it is unlikely there will be success with broader regulatory reform efforts. Domestic efforts to achieve such reforms have had some success, but a global regime for regulating domestic regulation would be difficult to achieve and might not be desirable. Negotiators should go after the low-hanging fruit, and be responsive to the needs of industry

\footnotetext{
${ }^{1}$ Department of Commerce, US-Mexico High Level Regulatory Cooperation Council, http://trade. gov/hlrce/ (last visited Nov. 15, 2013).
} 


\section{TRANSATLANTIC COOPERATION REGARDING 525}

and consumers by focusing their attention on issue areas where they can have the greatest impact ${ }^{2}$.

Currently, issues related to regulatory trade barriers are addressed in a number of forums, including the World Trade Organization and the ongoing Trans-Pacific Partnership (TPP) negotiations. Nonetheless, because of the emphasis being placed on this issue in the TTIP, this may be the best forum to push the issue forward. If done right, the TTIP could serve as a starting point for broader engagement on reducing the costly burden of regulatory divergence on international trade ${ }^{3}$. It must be underlined that, the ideal route for the reduction of regulatory divergence would be through a multilateral effort involving various actors from both government agencies and the private sector.

\section{MATERIALS AND METHODS}

Methodologically inclusive account breaks the transatlantic cooperation regarding China. The article sets out in general terms the importance of regulatory trade barriers, focusing on US-EU trade. It attempts to make the issues more concrete, by discussing a number of real world examples of such barriers. It then talks about how international regulatory cooperation can address these issues in the abstract, before considering previous efforts undertaken in trade agreements. The article offers examples of successful regulatory cooperation efforts in the hope that it will shed light on possible approaches to addressing regulatory divergences. The article suggests that such an approach may be best for the TTIP, and could eventually be multilateralized. The negotiations on a Transatlantic Trade and Investment Partnership are observed by various countries also by China P. R. The general theoretical approach will be of broad interest to economists interested in international questions especially transatlantic cooperation regarding China as well as to political scientists. The main method applied in this research was a method of scientific study. It was used the comparative method, the documentation method and statistical methods. Additionally, it used also, the methods of deductive and inductive forecasting.

\footnotetext{
${ }^{2}$ Lester S. and Barbee I., The Challenge of Cooperation: Regulatory Trade Barriers in the Transatlantic Trade and Investment Partnership, 16(4) JOURNAL OF INTERNATIONAL ECONOMIC LAW 847-867 (2013).

${ }^{3}$ Ibid.
} 


\section{DISCUSSION}

\section{A. The Regulatory Trade Barriers in USA-EU Foreign Trade Policy}

The idea of transatlantic regulatory cooperation has been around for many years. Previous attempts, on the whole, have been relatively ad hoc and piecemeal, focused more on fostering dialogue than actually solving regulatory discrepancies. The Trans-Atlantic Business Dialogue, established in 1995, brought together business interests on both sides of the Atlantic, in the hopes of developing strong public-private partnerships to allow products certified in one place to be accepted by the other. It was founded to deal with a major problem identified by its members, that is, competitiveness is hampered on both sides by excessive regulation and by differences between the EU and USA regulatory systems ${ }^{4}$. The organization, now the Trans-Atlantic Business Council, had some early success with mutual recognition agreements in areas such as telecommunications equipment, some medical devices, and other limited product areas ${ }^{5}$. However, the efforts seem to have lost momentum in recent years. Other efforts, such as the USA-EU High Level Regulatory Cooperation Forum, have also produced limited results of a substantive nature, though it has encouraged an ongoing dialogue of the issues.

At this stage, though, little information is available on what specific issues will be addressed or how liberalization in this area will be accomplished in the context of the TTIP. A brief explanation is included in the report of the US-EU High Level Working Group (HLWG), which was established in November 2011 by the US and EU political leaders to identify options for strengthening the US-EU trade and investment relationship - that provides a framework for the talks ${ }^{6}$. In addition to the agenda proposed by the HLWG, the negotiators have committed themselves to find new rules on issue of global concern such as protection of intellectual property and treatment of products and services provides by state-owned enterprises ${ }^{7}$.

First, the report suggests expanding on the existing technical barriers to

\footnotetext{
${ }^{4}$ M. Egan, Constructing a European Market 256 (New York: Oxford University Press, 2003).

${ }^{5}$ Lester S. and Barbee I., The Challenge of Cooperation: Regulatory Trade Barriers in the

Transatlantic Trade and Investment Partnership, 16(4) JOURNAL OF INTERNATIONAL ECONOMIC LAW 847-867 (2013).

${ }^{6}$ Final Report, High Level Working Group on Jobs and Growth (Feb. 11, 2013), http://www.ustr.gov/.

${ }^{7}$ Ries Ch., The Strategic Significance of TTIP in THE GEOPOLITICS OF TTIP REPOSITIONING THE Transatlantic Relationship For Changing World (D. S. Hamilton ed., Centre for Transatlantic Relations, Paul H. Nitze School of Advanced International Studies, John Hopkins University, Washington DC. 2014)
} 


\section{TRANSATLANTIC COOPERATION REGARDING 527}

trade (TBT) ${ }^{8}$ (Agreement on Technical..., 1994) and sanitary and phytosanitary measures (SPS) ${ }^{9}$ (Agreement on the Application..., 1994) rules of the WTO, by creating "TBT-plus" and "SPS-plus" chapters ${ }^{10}$. Part of this would involve substantive obligations, and part would involve new procedures. Through the substantive obligations, the parties would be bringing issues of regulatory protectionism into the TTIP. Regulatory protectionism is an important concern ${ }^{11}$, and putting constraints on protectionist domestic regulations is one of the core goals of international trade rules. It is not clear how existing WTO rules-either the TBT or SPS agreements, or even more general rules such as the GATT or the GATS-are insufficient in this area. These rules draw a delicate balance between imposing international disciplines on trade measures and respecting national autonomy ${ }^{12}$.

It must be emphasized that during the period October 15, 2012 to May 15, 2013 WTO Members submitted 858 regular Technical Barriers to Trade (TBT) notifications; $80 \%$ of these notifications were submitted by developing country Members (including Commonwealth of Independent States (CIS) Members, with 34 notifications, and LDC Members, with 40 notifications). The largest number of notifications received during the reviewed period came from the Kingdom of Saudi Arabia (118 notifications). Other significant notifying Members were the United States (66), Israel (54), Kenya (46), China (43), and the European Union (40) ${ }^{13}$.

With respect to the stated objectives indicated in the regular notifications submitted, the overwhelming majority (more than $80 \%$ ) related either to the protection of human health or safely (564) or to the protection of the environment (134). Other relevant stated objectives included: Consumer information and labelling (52) and prevention of deceptive practices and consumer protection (36) ${ }^{14}$.

\footnotetext{
${ }^{8}$ Agreement on Technical Barriers to Trade, Apr. 15, 1994, WTO Agreement, Annex 1A, Results of the Uruguay Round of Multilateral Trade Negotiations: The Legal Texts, at 138.

${ }^{9}$ Agreement on the Application of Sanitary and Phytosanitary Measures, Apr. 15, 1994, WTO Agreement, Annex 1A, Results of the Uruguay Round of Multilateral Trade Negotiations: The Legal Texts, at 69.

${ }^{10}$ Final Report, op.cit.

${ }^{11}$ Watson K. W. and James S., Regulatory Protectionism: A Hidden Threat to Free Trade, PoLICY ANALYSIS, Apr. 9, 2013, at 723. Available at http://www.cato.org/publications/policy-analysis/ regulatory-protectionism-hidden-threat-free-trade (last visited Nov. 15, 2013).

${ }^{12}$ Lester S. and Barbee I., The Challenge of Cooperation: Regulatory Trade Barriers in the Transatlantic Trade and Investment Partnership, 16(4) JOURNAL OF INTERNATIONAL ECONOMIC LAW $847-867$ (2013).

${ }^{13}$ WT/TPR/OV/W/7, Trade Policy Review Body, REPORT TO THE TPRB FROM THE DireCtORGeneral on Trade-Related DeVelopment (Mid-October 2012 to mid-May 2013). July 5, 2013 (13-3559), at 1/72.

${ }^{14}$ Ibid.
} 
Specific trade concerns (STCs) with respect to TBT measures taken by Members can be raised at any of the three regular meetings of the TBT Committee each year; 21 new STCs were raised during the two Committee meetings that fell during the reviewed period (the November 2012 and March 2013 meetings) (Chart 1).

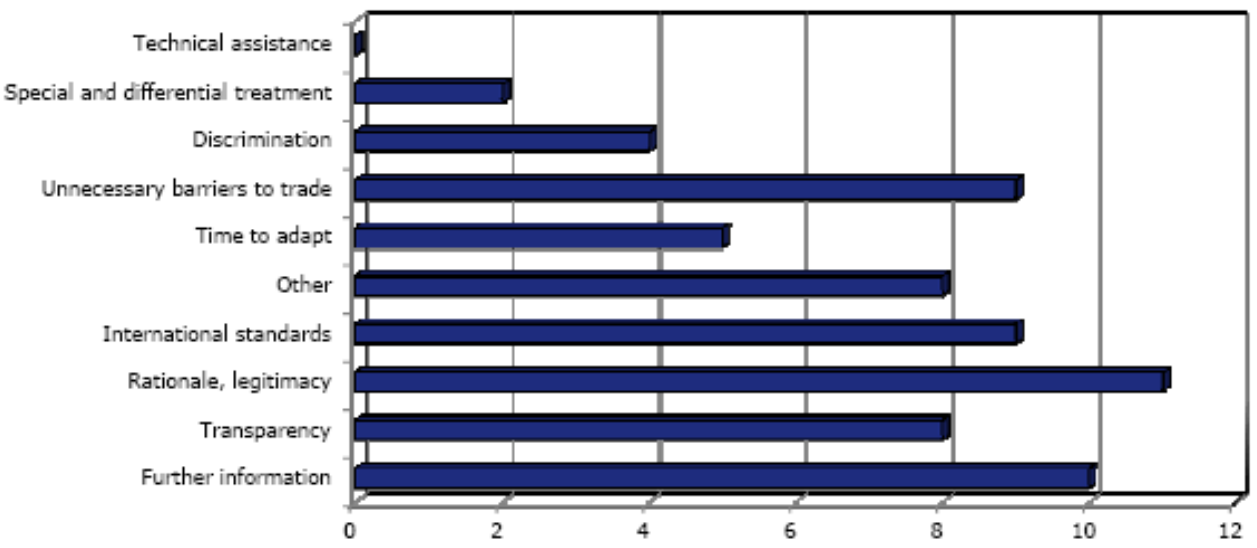

Chart 1 Issues Raised in New TBT Specific Concerns*.

From October 15, 2012 to May 15, 2013 (covering November 2012 and March 2013 TBT meetings). Source: WTO Secretariat., WT/TPR/OV/W/7 5 July 2013 (13-3559) Page: 1/72 Trade Policy Review Body, REPORT TO THE TPRB FROM THE DIRECTOR-GENERAL ON TRADE-RELATED DEVELOPMENTS (Mid-October 2012 to mid-May 2013).

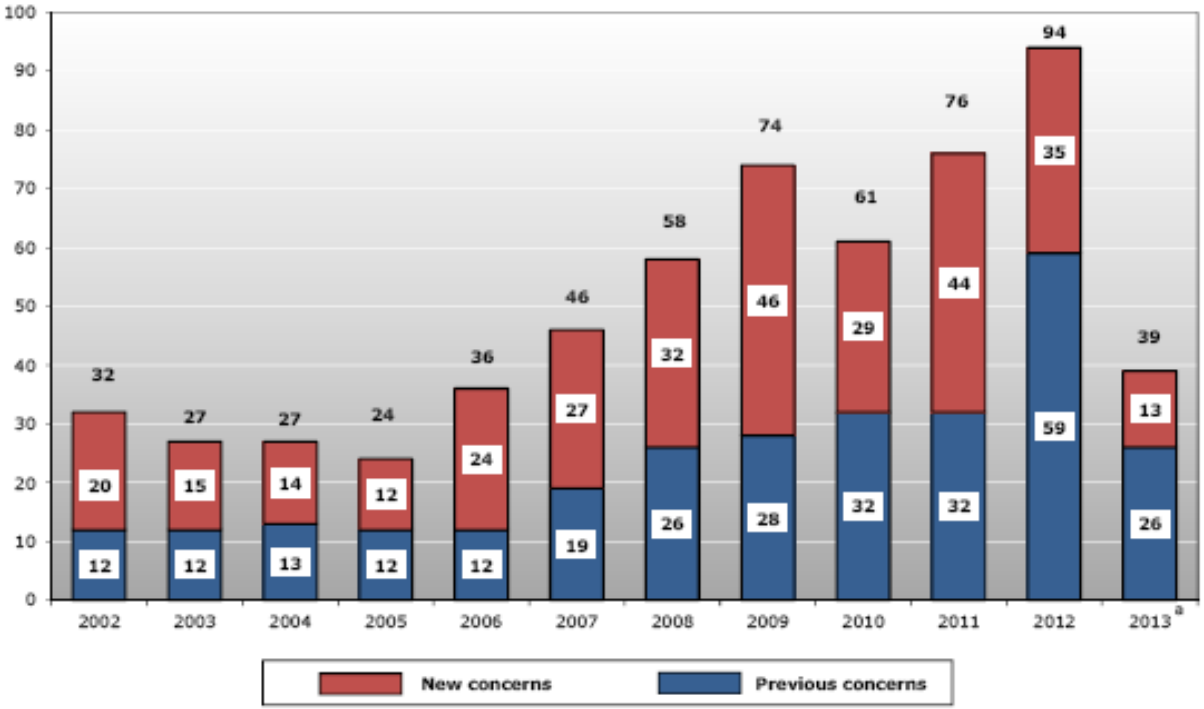

a. Data for 2013 includes only those STCs raised at the TBT Committee meeting of the year (held in March 2013).

Chart 2 Number of TBT Specific Trade Concerns Raised Per Year.

Source: WTO Secretariat., WT/TPR/OV/W/7 5 July 2013 (13-3559) Page: 1/72 Trade Policy Review Body, REPORT TO THE TPRB FROM THE DIRECTOR-GENERAL ON TRADE-RELATED DEVELOPMENTS (Mid-October 2012 to mid-May 2013). 


\section{TRANSATLANTIC COOPERATION REGARDING 529}

It is important underline that since 1995, and up to May 15, 2013, Members have raised 376 STCs in the TBT Committee. The number of STCs raised and discussed in the Committee has grown over the last five years (Chart 2). Although in 2012 Members raised fewer new STCs as compared to 2011, the total number of STCs discussed in the TBT Committee continue to mark an upward trend ${ }^{15}$.

In the period from October 2012 through March 2013, 613 sanitary and phytosanitary measures (SPS) notifications (regular and emergency) were submitted to the WTO. Notifications from developing-country Members accounted for $66 \%$ of the total number. In the previous six-month period, the total number of notifications was higher and the proportion of measures notified by developing-country Members lower: From April through September 2012, a total of 696 notifications (regular and emergency) were submitted, of which 54\% were by developing-country Members.

The number of notifications of emergency measures also dropped compared with the previous period (Chart 3). The share of emergency notifications submitted by developing-country Members was broadly similar to that of the previous period. From October 2012 through March 2013, $79 \%$ of the 39 notifications of emergency measures were submitted by developing-country Members. For the previous period (April-September 2012), $81 \%$ of the 58 emergency notifications were submitted by developing-country Members. This high proportion of emergency measures notified by developing-country Members might stem from the fact that they do not have extensive SPS regulatory systems as developed-country Members do, and consequently, when facing emergency challenges, they are more likely to have to introduce new regulations or change existing ones ${ }^{16}$.

It is important underline that many Members are following the recommendation to notify SPS measures even when these are based on a relevant international standard, as this substantially increases transparency regarding SPS measures. Of the 409 regular notifications (excluding addenda) submitted from October 2012 to March 2013, 215 (53\% of the total) indicated that an international standard, guideline or recommendation was applicable to the notified measure (Chart 4). Of these, $80 \%$ indicated that the proposed measure was in conformity with the existing international standard.

\footnotetext{
${ }^{15}$ Ibid.

${ }^{16} \mathrm{Ibid}$
} 


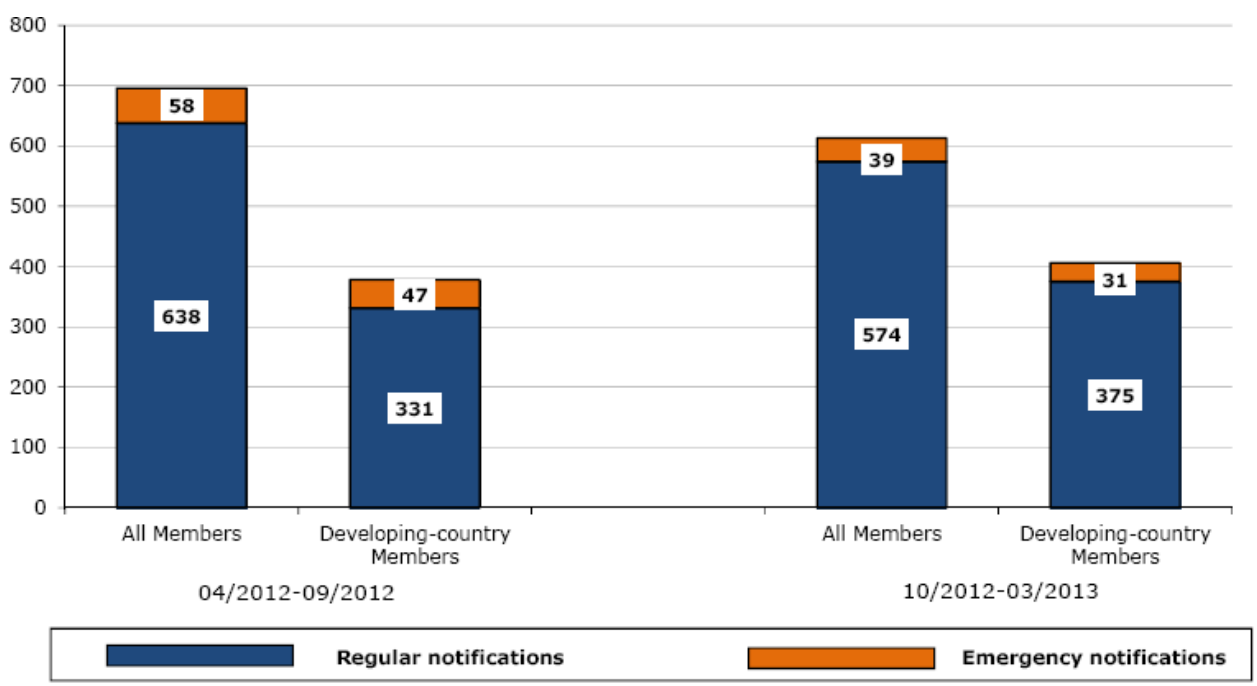

Chart 3 Number of SPS Notification.

Source: WTO Secretariat., WT/TPR/OV/W/7 5 July 2013 (13-3559) Page: 1/72 Trade Policy Review Body REPORT TO THE TPRB FROM THE DIRECTOR-GENERAL ON TRADE-RELATED DEVELOPMENTS (Mid-October 2012 to mid-May 2013).

International standards often provide useful guidance regarding measures to address disease outbreaks and other emergency situations. Indeed, $83 \%$ of the 30 emergency notifications (excluding addenda) submitted from October 2012 to March 2013 indicated that an international standard, guideline or recommendation was applicable to the notified measure (Chart 4). Of these, 96\% indicated that the measure was in conformity with the existing international standard. Of the 574 regular notifications submitted from October 2012 to March 2013, the majority were related to food safety and the protection of humans from animal diseases or plant pests ${ }^{17}$. The objective of an SPS measure falls under one or more of the following categories: (1) Food safety, (2) animal health, (3) plant protection, (4) protect humans from animal/plant pest or disease, and (5) protect territory from other damages from pests. Members are required to identify the purpose of the measure in their notifications. It is not uncommon for more than one objective to be identified for a measure. The remaining notifications related to plant protection, animal health and to the protection of the Member's territory from other damage from pests. Several of the regular notifications identified more than one objective per measure.

It must be emphasized that of the 39 emergency measures notified in the same period, the majority related to animal health, followed by measures

${ }^{17} \mathrm{Ibid}$ 


\section{TRANSATLANTIC COOPERATION REGARDING 531}

related to plant protection, the protection of humans from animal diseases or plant pests, food safety, and protection of the Member's territory from other damage from pests. Similarly, the majority of emergency notifications during this period identified more than one objective per measure (Chart 5).

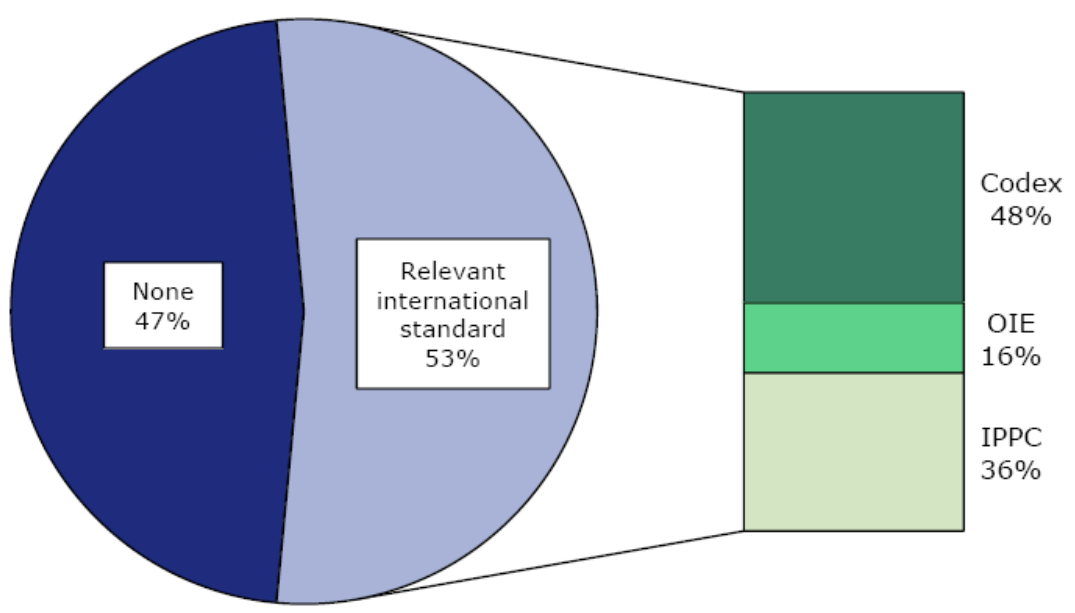

Chart 4 Regular SPS Notification and International Standards.

Source: WTO Secretariat., WT/TPR/OV/W/7 5 July 2013 (13-3559) Page: 1/72 Trade Policy Review Body REPORT TO THE TPRB FROM THE DIRECTOR-GENERAL ON TRADE-RELATED DEVELOPMENTS (Mid-October 2012 to mid-May 2013).

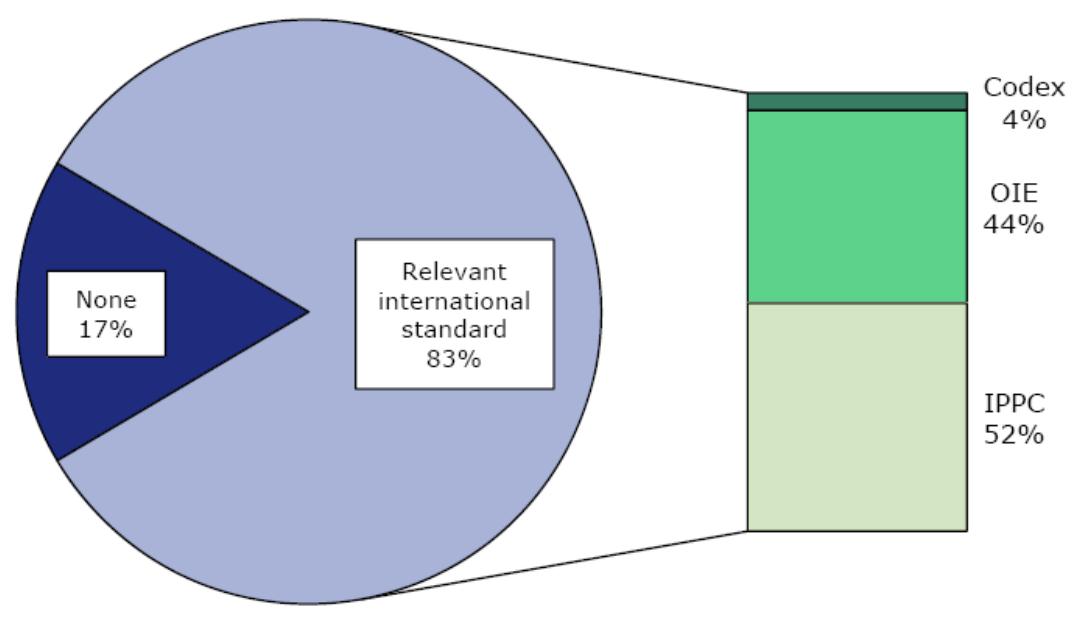

Chart 5 Emergency SPS Notification and International Standards.

Source: WTO Secretariat., WT/TPR/OV/W/7 5 July 2013 (13-3559) Page: 1/72 Trade Policy Review Body REPORT TO THE TPRB FROM THE DIRECTOR-GENERAL ON TRADE-RELATED DEVELOPMENTS (Mid-October 2012 to mid-May 2013). 
While there is no formal provision for "counter notification", concerns regarding the failure to notify an SPS measure, or regarding a notified measure can be raised as a specific trade concern (STCs) at any of the three regular meetings of the SPS Committee each year. In the two Committee meetings of October 2012 and March 2013, 14 new trade concerns were raised. Four of these STCs related to food safety, six to animal health, three to plant health, and one to other concerns.

The goal of trade agreements should be putting limits on protectionist policies, without impeding governments from fulfilling their responsibilities. There is an extensive jurisprudence at the WTO that applies and elaborates the rules with this balance in mind. Upsetting the current balance could be problematic. Sensitive issues such as the EU's treatment of genetically modified foods and hormone treated meat are difficult and have not been fully resolved at the $\mathrm{WTO}^{18}$, and suggestions that new TTIP rules will help should be looked at with some skepticism.

In the negotiations for a TPP, there has been an effort to expand the US regulatory model to other trading partners. Whether regulatory effectiveness can be achieved anywhere is unclear; Even domestic reforms along these lines are quite difficult. But trying to reconcile differences between two mature regulatory models like the USA and EU will be a particular challenge. Both sides have spent decades developing their regulatory processes, and convergence will not be easy.

Finally, the report talks about regulatory differences ${ }^{19}$. Regulatory differences (or "divergence") exist when government agencies in different countries have varying regulatory requirements or processes in the same policy area. Such differences result in higher costs for businesses in a number of ways. First, companies have to comply with multiple certification and testing requirements or approval processes in order to get a product approved for sale, which takes time and money. And second, the different regulations may result in the costly need for additional production processes in order for the product to meet the different standards of each market ${ }^{20}$.

It must be emphasized that regulatory divergence across countries can arise for a number of reasons. For one thing, policy objectives may vary. If countries are trying to achieve different goals, their regulations are unlikely to correspond. But even where policy objectives are similar, regulating

\footnotetext{
${ }^{18}$ Proposed Agenda, WT/ DSB/W/513, (Sep. 23, 2013).

${ }^{19}$ Final Report, op.cit.

${ }^{20}$ Lester S. and Barbee I., The Challenge of Cooperation: Regulatory Trade Barriers in the Transatlantic Trade and Investment Partnership, 16(4) JOURNAL OF INTERNATIONAL ECONOMIC LAW $847-867$ (2013).
} 


\section{TRANSATLANTIC COOPERATION REGARDING 533}

through an isolated process, in which national agencies make decisions without thinking about what their foreign counterparts are doing, can lead to differences in regulation ${ }^{21}$.

The impact will vary depending on the nature of the divergence. It may be that, due to different regulatory requirements, two markets end up somewhat isolated, with products made in each essentially restricted to the domestic market. Alternatively, one market might have regulations that are more flexible, and thus products are excluded only from the market with stricter regulations ${ }^{22}$. It must be important underline that there is a separate approval process in each market, which means that while products can be sold in both markets, there is an added cost from going through multiple regulatory reviews.

\section{B. The Nature and the Promoters of the Transatlantic Trade and Investment Partnership}

Examining the nature of the US-EU trading relationship, it is not hard to see why regulatory issues are of such high importance. A large portion of USA trade with the EU is intra-industry and intra-firm, which means the TTIP is likely to bring about changes within existing value chains rather than relocation of whole industries ${ }^{23}$. The major barriers to trade and investment, then, go beyond tariffs, and also include bureaucratic red-tape caused by incompatible rules and regulations that impede and slow down the free movement of goods and services ${ }^{24}$.

It is very important to understand the nature of the projected gains. The magnitude and the range of the total impact of the TTIP on GDP were taken from Felbermayr et al. (2013a) who give estimates for the United States, the 27 countries of the European Union, and 98 countries of the rest of the world ${ }^{25}$. With their macro general equilibrium model, Felbermayr et al. (2013a) consider two scenarios ${ }^{26}$. A "low impact" scenario calculates only the direct effect of reducing trade costs by eliminating existing tariffs in all

\footnotetext{
${ }^{21}$ Ibid.

22 Ibid.

${ }^{23}$ The Transatlantic Trade and Investment Partnership, Why Does it Matter?, OECD, (Feb. 13, 2013), http://www.oecd.org/trade/TTIP.pdf (last visited Nov. 15, 2013).

${ }^{24}$ Lester S. and Barbee I., The Challenge of Cooperation: Regulatory Trade Barriers in the Transatlantic Trade and Investment Partnership, 16(4) JOURNAL OF INTERNATIONAL ECONOMIC LAW 847-867 (2013).

${ }^{25}$ G. Felbermayr, B. Heid, S. Lehwald, Transatlantic Trade and Investment Partnership (TTIP) Who Benefits from a Free Trade Deal? Part 1: Macroeconomic Effects, available at http://issuu.com/bertelsmannfoundation/ docs/ttip-ged study (June 17, 2013). ${ }^{26} \mathrm{Ibid}$
} 
sectors. The "high impact" scenario adds the removal of non-tariff barriers and projects the impact of the increase in trade activity on investments and economic growth ${ }^{27}$.

The promoters of the Transatlantic Trade and Investment Partnership have tried to sell the agreement to the public on both sides of the Atlantic as a way to boost growth and create jobs. At a time when both the US and European economies are still suffering from the effects of the recession, anything that boosts growth sounds appealing. However, a closer look at the projections indicates that the promised growth is not likely to amount to much. Furthermore, there will likely be negative aspects to any deal that could far outweigh any gains.

For the purpose of the present study Felbermayr et al. (2013b) projections of the cumulative change in GDP with the low or high scenario were converted into annual growth rates over a decade, the time needed for almost full impact ${ }^{28}$. It was further assumed that the effect of the TTIP on GDP would begin in 2015 and end in 2025, but the simulations continued until 2030 to absorb any residual dynamic effect ${ }^{29}$.

The Centre for Economic Policy Research in the United Kingdom uses also a standard economic model to project the fully realized impact of the TTIP in 2027. In what it considers the most likely scenario for a final deal, its model projects that the TTIP would increase the GDPs of the EU and the US by 0.5 and 0.4 percentage points respectively. While more growth is generally better than less growth, the projected gains for the EU come to less than 0.04 percentage points annually. For the United States, the projected gains are 0.03 percentage points a year. Thus, the growth increases will be far too small to notice in the annual GDP data ${ }^{30}$.

Moreover, this growth does not imply additional job growth, as the Centre made clear in its summary. The TTIP is assumed to increase the efficiency with which a particular supply of labor is used; It does not

\footnotetext{
${ }^{27}$ Buongiorno J., Rougieux P., Barkaoui A., Zhu S., Harou P., Potential Impact of a Transatlantic Trade and Investment Partnership on the Global Forest Sector, 20 JOURNAL OF FOREST ECONOMICS 252-266 (2014) (Department of Forest Economics, Swedish University of Agricultural Sciences, Umeå. Published by Elsevier $\mathrm{GmbH}$ ).

${ }^{28}$ G. Felbermayr, M. Larch, L. Flach, E. Yalcin, S. Benz, Dimensionen und Auswirkungen eines Freihandelsabkommens zwischen der EU und den USA. Studie im Auftrag des Bundesministeriums für Wirtschaft und Technologie, München, available at http://www.cesifogroup.de/portal/page/portal/DocBase_Service/studien/ifo_AH_2013_TAFTA_Endbericht.pdf. ${ }^{29}$ Buongiorno J., Rougieux P., Barkaoui A., Zhu S., Harou P., Potential Impact of a Transatlantic Trade and Investment Partnership on the Global Forest Sector, 20 JOURNAL OF FOREST ECONOMICS 252-266 (2014).

${ }^{30}$ Lester S. and Barbee I., The Challenge of Cooperation: Regulatory Trade Barriers in the Transatlantic Trade and Investment Partnership, 16(4) JOURNAL OF INTERNATIONAL ECONOMIC LAW 847-867 (2013).
} 


\section{TRANSATLANTIC COOPERATION REGARDING 535}

increase the demand for labor. In fact, the summary explicitly notes the agreement could lead to job losses in the short run, as lower cost imports displace some workers.

Furthermore, the projections only consider ways in which the agreement may speed growth by reducing barriers. There are also likely to be provisions that slow growth by increasing barriers, most notably in the area of patent protection, especially for prescription drugs.

If the deal strengthens patent or related protections for drugs, then it will lead to higher drug prices. This will drain money out of the economy and lead to more inefficiency in the same way that higher tariffs on imports lead to higher prices and inefficiency. The difference is that tariffs are rarely more than twenty or thirty percent in advanced economies, where as patent protection can raise the price of drugs by several thousand percent above their free market price ${ }^{31}$.

There are other elements of the TTIP that should raise concerns on both sides of the Atlantic. Since formal trade barriers between the EU and US are already low, the negotiations are mostly focused on non-trade issues. This will involve areas of regulation that are currently under the control of national or subnational governments. For example, the TTIP could include provisions on how genetically modified foods are regulated. TTIP provisions could make restrictions on the sale or planting of GMO crops an unfair trade practice. They could also limit the ability of governments to impose labeling requirements.

The TTIP could also include provisions on fracking, the process of drilling for deep pools of natural gas or oil. Federal legislation in the United States has exempted companies engaged in fracking from complying with decades-old environmental restrictions that were designed to ensure the safety of drinking water. As a result, there have been numerous complaints that fracking operations have resulted in the contamination of drinking water near fracking sites. However, these allegations are difficult to assess, because the oil and gas companies are not required to disclose the chemicals they used in the fracking process.

There are many other areas where regulations that would not be approved by national or subnational governments may effectively be imposed through the TTIP. This is in fact one of the main motivations of the TTIP: It provides a channel around the democratic process in both the EU and the US. Regulatory changes that may not be possible due to domestic political considerations may be imposed through a trade agreement which

\footnotetext{
${ }^{31} \mathrm{Ibid}$.
} 
will be presented to elected legislatures on both sides of the Atlantic as an all or nothing proposition.

This is perhaps the clearest in the case of investor-state dispute settlement (ISDS). This is a process that the United States has established as part of numerous trade deals over the last three decades. It involves the creation of special panels, outside the control of the government in question, to decide issues related to disputes with foreign investors. For example, if a US company felt that a regulation imposed by the Mexican government was unfairly imposing costs on it, the company could take its complaint to a special panel established for this purpose rather than going through Mexico's legal system.

This might make sense in certain situations and may even be mutually beneficial in countries that lack a well-functioning legal system. Foreign companies may be reluctant to invest in a developing country if they are concerned that they would not be able to get adequate redress through that country's legal system. By setting up an alternative mechanism, potential foreign investors can be more confident that laws will be fairly applied. Independent panels that are beyond the government's control give investors more protection than a promise from the government. Even if the government is sincere in such a promise, a new government may not feel bound by a prior government's commitment.

Thus, ISDS may in fact make sense for developing countries as a way to promote foreign investment. However, it is much more difficult to see the merits of this argument for the TTIP, in which all of the countries involved have long-established legal traditions and many decades of experience with independent judiciaries. It is difficult to believe that courts in Denmark, Germany or the United States could not be trusted to treat foreign investors fairly.

On the other hand, it is reasonable for citizens of the EU and the US to question whether the new legal system being set up under the TTIP can be counted on to respect the rights and interests of anyone other than foreign investors. This does not mean that the ISDS will necessarily have a proinvestor bias, but if there is no obvious anti-investor bias in the current legal system, then why is it necessary to establish a new dispute settlement mechanism?

In short, the TTIP is much more than a free trade agreement designed to reduce tariffs and quotas. It would create a structure of regulation and a new legal system that would remove authority in a wide variety of areas from democratically elected bodies and the existing legal structure. TTIP can be both a symbolic and practical assertion of Western renewal, vigor 


\section{TRANSATLANTIC COOPERATION REGARDING 537}

and commitment, not only to each other but to high rules-based standards and core principles of international order. It can be assertive, yet need not be aggressive. It challenges fashionable notions about a "weekend West"

TTIP's goal is to eliminate all impediments in bilateral trade in goods and investments according to the principle of origin. For the trade in services, the aim is to obtain improved market access and to address the operation of any designated monopolies and state-owned enterprises ${ }^{33}$.

Since the projected economic gains from this deal are relatively modest, there is no reason that anyone should feel an irrepressible need to grab at whatever final deal comes out of the negotiations. It would be best if any moves towards superseding the established systems be done with careful consideration and not the rushed, all-or-nothing approach-envisioned by the governments negotiating the TTIP. If the TTIP timeline does not allow for thorough debate, it can always come back to the issue of reducing trade barriers later.

\section{Interrelationship between Regulatory Standards and International Cooperation in the TTIP}

In theory, problems of regulatory divergence can be solved without international cooperation. Just like with free trade in general, governments could liberalize unilaterally. In the context of regulations, governments could simply declare that products complying with foreign regulations in the same area will be deemed acceptable for import. US regulators could accept EU headlights; And EU regulators could accept US GM foods. However, in practice, domestic political resistance, sometimes for protectionist purposes, often means that solutions to these problems will require international cooperation. Government regulators from different countries need to sit down and hash out the issues ${ }^{34}$.

How should international cooperation work in practice? There are two common methods-both of which are referred to in the HLWG

\footnotetext{
${ }^{32}$ D. S. Hamilton, TTIP's Geostrategic Implications in THE GeOPOLITICS OF TTIP RePOSITIONING THE TRANSATLANTIC RELATIONSHIP FOR CHANGING WoRld (Centre for Transatlantic Relations, Paul H. Nitze School of Advanced International Studies, John Hopkins University, Washington DC. 2014).

${ }^{33}$ Straubhaar T., TTIP's Don't Lose Momentum! in The Geopolitics of TTIP Repositioning THE Transatlantic Relationship FOR Changing World (D.S. Hamilton ed., Centre for Transatlantic Relations, Paul H. Nitze School of Advanced International Studies, John Hopkins University, Washington DC. 2014).

${ }^{34}$ Lester S. and Barbee I., The Challenge of Cooperation: Regulatory Trade Barriers in the Transatlantic Trade and Investment Partnership, 16(4) JOURNAL OF INTERNATIONAL ECONOMIC LAW $847-867$ (2013).
} 
report ${ }^{35}$ - which have been used to deal with regulatory divergence: Harmonization and mutual recognition ${ }^{36}$.

Harmonization implies the alignment of regulations to a single best practice. Usually a voluntary agreement, harmonization can be based on a reference to international standards from a standard-setting body, or simply involve coordination among nations. Countries basically agree to converge on a single standard or regulation. This is usually the most difficult way to achieve regulatory cooperation, in part because countries are reluctant to adjust their standards, and also because the harmonization of standards requires complete consensus ${ }^{37}$.

Mutual recognition can be achieved through mutual recognition agreements or the acknowledgement of regulatory equivalence. Mutual recognition agreements approve testing and certification processes of other countries as acceptable for allowing sale in their own country. This method is especially useful in eliminating duplicative testing and certification processes. Recently, this approach was employed in a mutual recognition agreement between the USA and Israel in relation to telecommunications equipment: Israeli regulatory authorities will accept tests that recognized USA laboratories perform to determine the conformity of telecommunications equipment with Israeli technical requirements, rather than requiring additional testing by Israeli laboratories in order for American products to be sold in Israel ${ }^{38}$.

Efforts to deal with regulatory barriers at the GATT/WTO eventually resulted in the TBT Agreement, which reinforces traditional GATT rules on non discrimination, and also goes a bit further to deal with the trade effects of burdensome regulation. Current efforts in the TBT Committee involve work on good regulatory practices, including developing a list of voluntary principles and mechanisms that represent best practices in developing and applying regulations ${ }^{39}$.

Cooperation could occur organically, of course, outside the context of an international agreement. Regulators from different countries could

\footnotetext{
${ }^{35}$ Final Report, op.cit.

${ }^{36}$ Lester S. and Barbee I., The Challenge of Cooperation: Regulatory Trade Barriers in the

Transatlantic Trade and Investment Partnership, 16(4) JOURNAL OF INTERNATIONAL ECONOMIC LAW 847-867 (2013).

${ }^{37}$ Ibid.

${ }^{38}$ New United States-Israel Telecommunications Agreement Eases Way for US Exports, USTR PRESS RELEASE, Oct. 15, 2012, available at http://www.ustr.gov/about-us/press-office/press-releases/2012/ october/ us-israel-telecomm-mou-eases-way-for-exports (last visited Nov. 15, 2013).

${ }^{39}$ WTO News Item, Members Continue to Discuss "Good Practices" for Technical Regulations (June 17-20, 2013), http://www.wto.org/english/news_e/news13_e/tbt_17jun13_e.html (last visited Nov. 15, 2013).
} 


\section{TRANSATLANTIC COOPERATION REGARDING 539}

simply sit down with each other and coordinate their diverging regulations. But this does not happen often in practice and has not occurred between the USA and the European Union, and there is little reason to think it will at any time soon. As a result, a formal mechanism to push this process along would be of great value $e^{40}$. The private sector needs a better way to point out the problems it is experiencing, and regulators must be given an opportunity to cooperate with their counterparts in other countries. The question then becomes: What should this mechanism look like? One approach that has been put forward would focus on requiring domestic regulators to look at what their colleagues abroad are doing ${ }^{41}$.

This approach emphasizes the role of regulators themselves and their decision-making process. While there might be some value to this, it also has the potential to be more burdensome than helpful. If every regulation that has an impact on trade-i.e. just about all regulations-requires consideration of how the other side regulates the same issue, the role of the bureaucracy in dealing with these issues could actually increase, and as a result this approach may actually raise more problems than it solves.

Instead of turning first to the regulators, a better approach to regulatory cooperation would be to focus attention on the views of the private sector, which faces the responsibility of meeting multiple government requirements, and which is in the best position to identify the costs and inefficiencies of regulatory divergences in trade. If business and consumer groups are not even concerned about a particular area of regulation, burdening the regulators with extra work is unnecessary. Thus, one of the main goals of the regulatory cooperation process should be to facilitate the involvement of producers, distributors and consumers in a process which provides for direct contact with the relevant government agencies. This further assists in identifying the priority sectors that need the most immediate attention and would yield the greatest economic benefit if divergences are narrowed ${ }^{42}$.

Private sector involvement could come at two stages. First, during the initial rule-making process for new regulations, there could be requests for input on potential conflicts with other countries' regulations. This would be

\footnotetext{
${ }^{40}$ Trade Cross-cutting disciplines and Institutional provisions (2013). The European Commission Makes Reference to Just Such a Formal Body. Available at http://trade.ec.europa.eu/doclib/ docs/2013/july/tradoc_151622.pdf (last visited Nov. 15, 2013).

${ }^{41}$ Lester S. and Barbee I., The Challenge of Cooperation: Regulatory Trade Barriers in the Transatlantic Trade and Investment Partnership, 16(4) JOURNAL OF INTERNATIONAL ECONOMIC LAW 847-867 (2013).

${ }^{42}$ Lester S. and Barbee I., The Challenge of Cooperation: Regulatory Trade Barriers in the Transatlantic Trade and Investment Partnership, 16(4) JOURNAL OF INTERNATIONAL ECONOMIC LAW $847-867$ (2013).
} 
helpful in preventing new regulations from diverging right to begin with. Second, with regards to existing regulations, it is essential to have private sector input on how divergent rules hamper trade so that a discussion can even begin. Since regulatory convergence will be a long-term process, there needs to be a permanent forum where the private sector-businesses, consumers and other groups-can raise concerns with both existing and potential divergence ${ }^{43}$.

While the TTIP offers a good starting point, regulatory cooperation should eventually be done on a multilateral basis. The need for this is amplified by the growing trend of 21 st Century trade agreements that include issues outside the traditional scope of trade negotiations. Outgoing WTO Director-General Pascal Lamy has articulated this problem clearly, suggesting that "while bilateral tariff reductions can ultimately be multilateralized, a plethora of bilateral trade agreements will produce a multitude of regulatory standards with which businesses will struggle to comply" "44. This simply means that if regulatory cooperation is included in multiple trade agreements with different participants, the risk of creating more layers of contradiction and confusion greatly increases. For instance, how different will a regulatory cooperation chapter of the TPP be from the TTIP? Would it not be better to open up the discussion of regulatory burdens on trade to a wider grouping of countries, to maximize the area in which inefficiencies can be eliminated? ${ }^{45}$

Without getting into too much detail here, multilateral regulatory cooperation could be undertaken through an international forum of some sort. It need not be based on an enforceable treaty. A more flexible structure, based on the idea of agreed cooperation, may be preferable. The goal is not to push countries to take on difficult and sensitive legal obligations; Rather, it is to seek out regulatory issues where countries can voluntarily work together ${ }^{46}$.

Multilateralizing regulatory cooperation may be impossible at this moment, but there is still a great deal of value to be had from US-EU cooperation. Since the USA and EU make up almost half of world GDP and

\footnotetext{
${ }^{43}$ Ibid.

${ }^{44}$ P. Lamy, Putting Geopolitics Back at the Trade Table (Jan. 29, 2013). Speech at the IISS-Oberoi Discussion Forum in Delhi, http://www.wto.org/english/news_e/sppl_e/sppl264_e.html (last visited Nov. 15, 2013).

${ }^{45}$ Lester S. and Barbee I., The Challenge of Cooperation: Regulatory Trade Barriers in the Transatlantic Trade and Investment Partnership, 16(4) JOURNAL OF INTERNATIONAL ECONOMIC LAW 847-867 (2013).

${ }^{46}$ Ibid.
} 


\section{TRANSATLANTIC COOPERATION REGARDING 541}

$30 \%$ of total goods and services trade $e^{47}$, any agreement both sides can come to on regulatory issues could help set the tone and trajectory of future regulatory cooperation efforts involving other parties. The greater the number of countries involved in eliminating costly and duplicative regulatory processes, the greater the potential gains for consumers and producers alike. The TTIP negotiations can play an important role in leading the way on regulatory cooperation efforts, and their success or failure will determine how this issue is addressed in the future ${ }^{48}$. It is important to underline that in this new situation for the cooperation between EU and USA significant position has also China a big foreign partner for USA and EU.

All studies foresee a small impact of removing trade barriers alone, and a larger impact of eliminating non-tariff barriers. Some disagree on the potential impact on third countries. While the OECD (2005) suggests that reducing barriers to trade between the EU and US will have mostly positive spill over effects on third party countries such as Canada, Mexico, Turkey, Japan and China. Felbermayr et al. (2013a) estimate that third party countries will lose market share in the US and the EU due to the increased trade between the two regions, and that this will have a negative effect on their economies. Additionally Felbermayr et al. (2013a) foresee a decrease in trade within EU countries, for example a 23\% decrease in trade between France and Germany ${ }^{49}$.

Most national and international studies on the macroeconomic impact of transatlantic trade agreements are based on general equilibrium approaches, such as the Global Trade Analysis Project (GTAP) model ${ }^{50}$. It

\footnotetext{
${ }^{47}$ Final Report, op.cit.

${ }^{48}$ Lester S. and Barbee I., The Challenge of Cooperation: Regulatory Trade Barriers in the Transatlantic Trade and Investment Partnership, 16(4) JOURNAL OF INTERNATIONAL ECONOMIC LAW 847-867 (2013).

${ }^{49}$ Buongiorno J., Rougieux P., Barkaoui A, Zhu S., Harou P., Potential Impact of a Transatlantic Trade and Investment Partnership on the Global Forest Sector, 20 JOURNAL OF FOREST ECONOMICS $252-266(2014)$

${ }^{50}$ K. G. Berden, J. Francois, M. Thelle, P. Wymenga, S. Tamminen, Non-tariff Measures in EUUS Trade and Investment - an Economic Analysis. ECORYS Nederland BV, Rotterdam (2009); Francois J. , Manchin M., Norberg H., Pindyuk O., Tomberger P., Reducing Transatlantic Barriers to Trade and Investment - an Economic Assessment. Center for Economic Policy Research, London (2013), available at http://trade.ec.europa.eu/doclib/docs/2013/march/ tradoc150737.pdf; OECD, The Benefits of Liberalising Product Markets and Reducing Barriers to International Trade and Investment: The Case of the United States and the European Union. OECD Economics Department Working Paper No. 432 (2005), Available at http://search.oecd.org/officialdocuments/ displaydocumentpdf $/$ ?doclanguage $=$ en $\&$ cote $=\mathrm{ECO} / \mathrm{WKP} \% 282005 \% 2919$.
} 
can combine the GTAP database with trade gravity models ${ }^{51}$ into a general equilibrium model to project macroeconomic impacts of the TTIP in the US, the EU, and third countries like China.

It is interesting to explore the effect of proliferating deep regional agreements on coherence in international trade governance ${ }^{52}$. The WTO suggested that new international trade rules are being negotiated and decided outside the WTO where power differences are greater and where the principles of non-discrimination and reciprocity are absent. It also argued that TTIP are here to stay. Governments will need to ensure that regional agreements and the multilateral trading system are complementary and that multilateral disciplines minimize any negative effects from PTAs ${ }^{53}$. While the available literature suggests that deep integration rules are often non-discriminatory-for instance, provisions in the services or competition policy areas are often extended to non-members-certain provisions in regional agreements can contain discriminatory aspects that clash with the multilateral trading system. It has been shown that PTAs which make it more difficult to apply contingency measures to PTA partners may divert protectionist measures towards non-members ${ }^{54}$.

Deep provisions can also have a number of adverse systemic effects. For example, the important effects of regional regulatory harmonization can make it more difficult to multilateral rules. PTAs may not include thirdparty most-favored nation (MFN) clauses, thus effectively discriminating against other countries. Developed country exporters may view bilateral and regional rather than multilateral agreements as faster and easier routes for achieving their objectives, further weakening the principle of nondiscrimination.

With regard to services supply chains, some argue that their growth creates an additional need to re-examine and modernize current rules for services trade, as these rules were designed for a world where services were exported as final products from national firms, not a world where multiple firms supply stages of services production from multiple locations. Recent research on how differences in firms have an impact on trade policies

\footnotetext{
${ }^{51}$ P. Egger, M. Pfaffermayr, Structural Estimation of Gravity Models with Path-Dependent Market Entry. CEPR Discussion Paper No. DP8458 (2011), available at http://www.ssrn.com/abstract= 1889961.

52 Jackson R. J., Global Politics in the $21^{\text {ST }}$ Century (Cambridge University Press, New York, 2013).

${ }^{53}$ Krist W., Globalization and America's Trade Agreements (John Hopkins University Press, Baltimore, 2013).

${ }^{54}$ Prusa T. J. \& R. Teh, Protection Reduction and Diversion: PTAs and the Incidence of Antidumping Disputes, NBER Working Papers 16276, National Bureau of Economic Research, Inc. (2010).
} 


\section{TRANSATLANTIC COOPERATION REGARDING 543}

reveals a related concern. Ciuriak et al. (2011) point out at another difference between deep integration at the regional and at the multilateral level ${ }^{55}$. While heterogeneous firms trade models suggest that more importance should be granted to extensive than to intensive margin responses to trade opening, there is evidence suggesting that PTA have positive effects at the intensive margin and negative effects at the extensive margin, whereas the opposite is true of opening in the multilateral context.

\section{TTIP Impact for China}

TTIP is lazily portrayed as an effort to confront and isolated China. Yet is less about containing China than about the terms and principles guiding China's integration and participation in the global economy. China's burgeoning trade with both the United States and Europe attests to US and EU interests in engaging China, not isolating $\mathrm{it}^{56}$. TTIP, TPP and related initiatives are important instruments to help frame Beijing's choices-by underscoring China's own interests in an open, stable international system as well as the types of norms and standards necessary for such a system to be sustained. China itself has changed its position and signalled a willingness to join plurilateral talks on services. Its motivations remain unclear, but there is no denying that TTIP and related initiatives are injecting new movement and energy into efforts to open market and strengthen global rules ${ }^{57}$.

US and EU officials had a common conversation with the Chinese about the need to keep trade open while raising standards, especially with regard to health and safety. The result was a trilateral US-EU-China review process of consumer product safety, including biennial "summits" among relevant officials, which has had some modest success in gaining Chinese commitments to cooperate in applying product safety controls along supply and distribution chains; Promoting company management systems that incorporate safety into product design; Exchanging information regularly on major safety issues; Reinforcing consumer product traceability; Implementing the concept of seamless surveillance; And exploring jointly the possible convergence of consumer product safety requirements. Expansion of such cooperation in additional areas and with additional countries based on alignment of US and EU understandings regarding high

\footnotetext{
${ }^{55}$ Ciuriak D., B. Lapham, R. Wolfe, T. Collins-Williams and J. M. Curtis. Firms in International Trade: Towards a New Trade Policy (November 2011).

${ }^{56}$ Hamilton, D. S., op.cit.

${ }^{57}$ Ibid.
} 
levels of protection, promises to keep standards high while keeping markets open $^{58}$.

It must be underline that the access of P.R. China to the World Trade Organisation (November 2001) was the moment in which new trade rules became obligatory in this country. The WTO-through its agreements on safeguards and antidumping, offers some recourse for states to rein in the forces of free trade. However, many experts suggest that there are legal ambiguities in WTO regime that have limited invocation of safeguard measures ${ }^{59}$. These concerns have been fueled because there is increasing Chinese competition in week industries and because it is harder to request supplying countries to take grey measures such as VERA in agriculture and textiles. In the next five years after the access to the WTO China eliminated all kinds of quotas and other non-tariff barriers that slow down the inflow of foreign goods. Customs duties which were lowered were gradually reduced to an average of $9 \%$.

China is now the biggest exporter and receiver of foreign investments. This country is the world's number one exporter after taking the top spot from Germany in 2009. About $20 \%$ of China's exports go to the United States $^{60}$. The US is China's largest trading partner ${ }^{61}$. In 2010, US exports of goods to China jumped $32 \%$, to US $\$ 92$ billion. China was the secondlargest recipient of Foreign Direct Investment (FDI) in $2009^{62}$. China attracted $\$ 105.7$ billion in foreign direct investment in 2010 - the first time FDI in China crossed $\$ 100$ billion $^{63}$ (Chart 6, Chart 7).

China's weak currency-which is good for Chinese exports-also makes the yuan (RMB) become one of the most undervalued currencies in the so-called "Big Mac index", a measure of purchasing-power parity (Chart 8). While a Big Mac averages US\$3.71 in the US it can buy one in China for only 14.5 yuan (US\$2.18) in Beijing and Shenzhen on average ${ }^{64}$.

\footnotetext{
${ }^{58}$ Ibid.

${ }^{59}$ Kawase, T., Safeguard Under the WTO Regime Realities and Problems. RESEARCH \& REVIEW, (2004b). Available at http://www.rieti.go.jp (Accessed January 8).

${ }^{60}$ The World Bank, 2011.

${ }^{61}$ LaFleur 2010, China: Asia in Focus, http://www.china-mike.com/facts-about-china/economyinvestment-business-statistics/ (last visit Nov. 10, 2013).

${ }^{62}$ United Nations, 2010.

${ }^{63}$ China FDI Rises Strongly in January, Outlook Bright, Reuters, Feb. 17, 2011.

${ }^{64}$ Bun Fight, 2010.
} 


\section{TRANSATLANTIC COOPERATION REGARDING 545}

Stock of outward foreign direct investment

$\%$ of world total

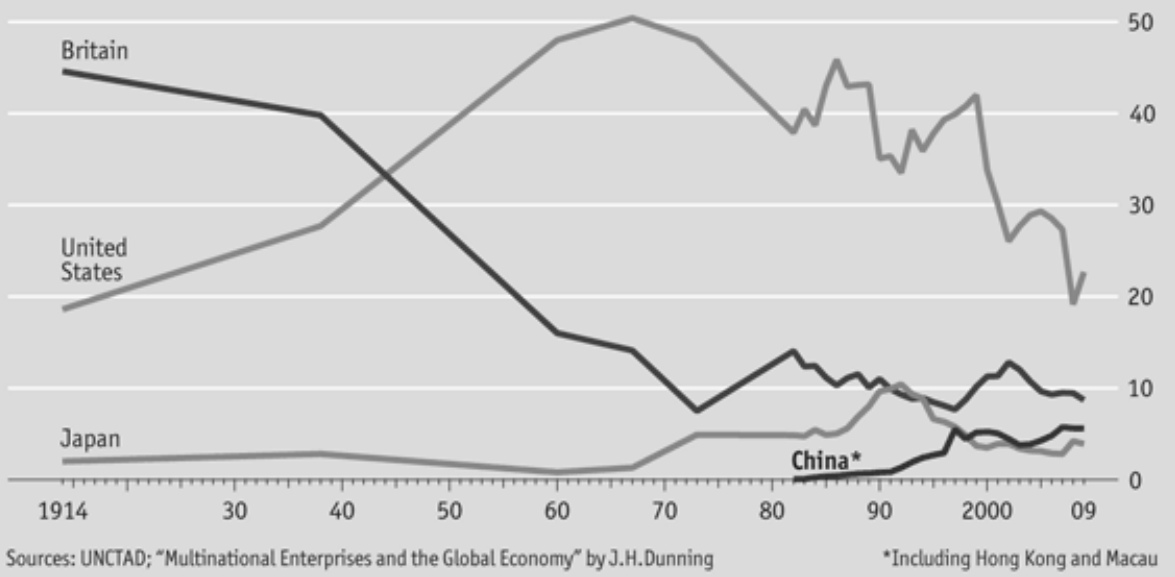

Chart 6 Stock of Outward Foreign Direct Investment (\% of World Total). Incuding Hong Kong and Macau.

Source: UNCTAD, Nov.10, 2013.

Foreign direct investment

FDI inflows, 2010 estimate, \$bn

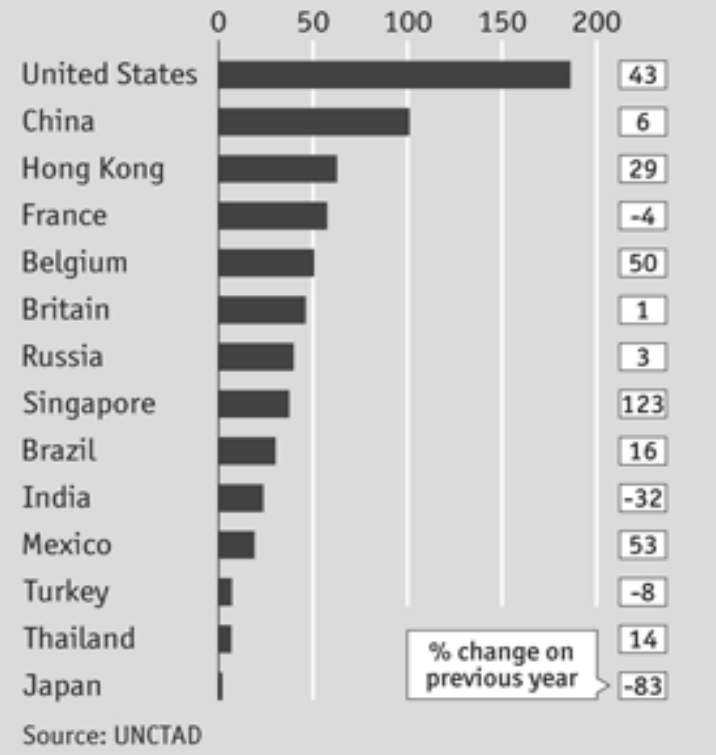

Chart 7 Foreign Direct Investment (FDI Inflows, 2010 Estimate, \$ bn). Source: UNCTAD, Nov.10. 2013. 


\section{Big Mac index \\ Local-currency under(-)/over(+) valuation against the dollar, \%}

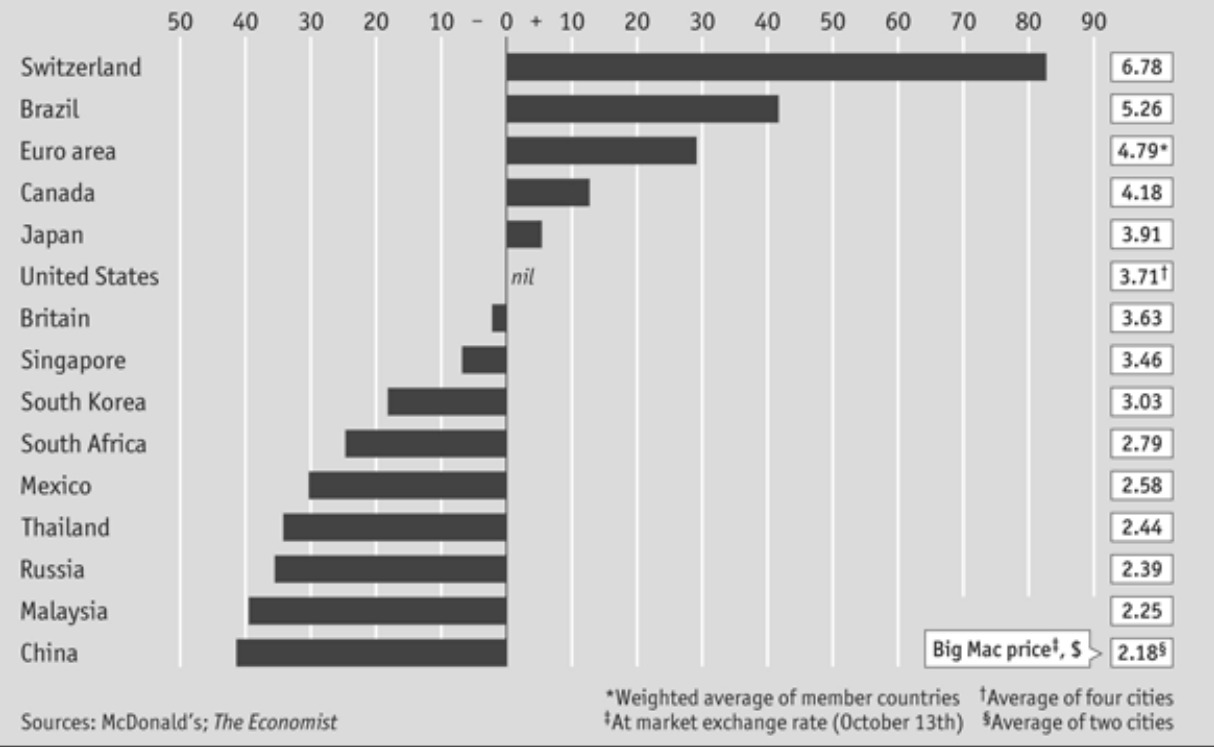

Chart 8 Big Mac Index (Local-Currency Under (-)/Over(+) Valuation Against the Dollar, \%).

Source, McDonald's; The Economist, http://www.china-mike.com/facts-about-china/economyinvestment-business-statistics/ Nov.10, 2013.

China is poised to make its money a global currency, which "could strengthen China's influence in overseas financial markets and begin to erode the dollar's dominance." China has over US\$1 trillion in foreign exchange reserves (exceeding Japan), and continue to grow around \$200 billion each year ${ }^{65}$. China's foreign-exchange reserves hit record highs on Q4 2010 to reach US \$2.85 trillion. The \$199 billion gain was the largest quarterly increase since Bloomberg data began in $1996^{66}$. China owns over $25 \%$ of US Treasury Bonds and is the largest creditor in the world ${ }^{67}$.

China is also the USA's largest creditor, holding more than $\$ 900$ billion worth of US. This value indicated Treasury bonds of the USA in October 2010. The second and third creditors are Japan and the UK.

China's emerging market stocks are predicted to quintuple in the next two decades-reaching a market value of around $\$ 80$ trillion by 2030 . The

\footnotetext{
${ }^{65}$ The World Bank 2011.

${ }^{66}$ China's Currency Reserves Rise to Record, Domestic Lending Exceeds Target, BloOMBERG, Jan. $11,2011$.

${ }^{67}$ Rediff Business Online, http://www.china-mike.com/facts-about-china/economy-investmentbusiness-statistics/ (last visit Nov. 10, 2013).
} 


\section{TRANSATLANTIC COOPERATION REGARDING 547}

Shanghai Stock Exchange was the fifth largest stock market in the world in December 2010 (market capitalization of US \$2.7 trillion). Eight of the ten largest stocks on the Shanghai Stock Exchange are state-controlled enterprises.

Currently, China is the largest destination for foreign investment ${ }^{68}$. Due to China's access to WTO, her share in the world trade will increase from $3 \%$ to $7 \%$ (in 1986 it was only $0.7 \%$ ). The results of the transition provide compelling evidence of the efficiency of market incentives. Other factors that have contributed to China's ascendancy to a world economic power include privatizing much of its industry, joining the World Trade Organization, formation of the Chinese Stock Exchange, passage of the Company Law (1993) and a multitude of corporate governance principles to protect shareholders and provide a framework of shifting from state to private ownership of capital ${ }^{69}$.

Further trade liberalization and improved framework policies would increase trade and promote growth. It must be emphasized that openness to trade is associated with higher incomes and growth and there are the need for new approaches to trade cooperation in light of the forces that are currently re-shaping international business. The key of trade developments within the broader socio-economic context is especially the rise of global supply chains, the general shift of trade power away from the West towards Asia and from US and EU towards China. A major factor was the even more remarkable transformation of China, as market reforms opened up its economy to foreign trade and investment, and unleashed an unprecedented growth dynamic that has continued, with only minor slowdowns in the new circumstances for the development of the global economy and the global trade.

In this context it is interesting to see that estimates by R. J. Tammen at al. (2000) anticipate that China will overtake the United States in midcentury $^{70}$. It is estimated also that by the year 2020 China will take the first position among the world powers (Table 1). Thus American dominance should endure until mid-century. Afterwards, Asian and China's demands for modification to the international system will likely increase, and unless resolved, will be increasingly likely to be imposed by force.

\footnotetext{
${ }^{68}$ Reuvid J., Business Insights—China, Kogan PAGE, (London and Philadelphia 2008).

${ }^{69}$ A. N. Doherty, F. V. Lu, China: Spectacular Growth and Inequality, 4(3) JOURNAL OF Business AND ECONOMICS 195-201 (2013).

${ }^{70}$ R. J. Tammen, J. Kugler, D. Lemke, A. Stam, M. Abdollahian, C. Al-Sharabati, B. Efird, and A. F. K. Organski, Power Transition (New York: Chatham House, 2000).
} 
Table 1 The Global Balance of Economic Powers in 2010 Versus 2020.

\begin{tabular}{|c|c|c|c|c|}
\hline Rank & Country - 2010 & GDP (U\$ million) & Country - 2020 & GDP (U\$ million) \\
\hline 1 & USA & $14,802,081$ & China & $28,124,970$ \\
\hline 2 & China & $9,711,244$ & USA & $22,644,910$ \\
\hline 3 & Japan & $4,267,492$ & India & $10,225,943$ \\
\hline 4 & India & $3,912,911$ & Japan & $6,196,979$ \\
\hline 5 & Germany & $2,861,117$ & Russia & $4,326,987$ \\
\hline 6 & Russia & $2,221,755$ & Germany & $3,981,033$ \\
\hline 7 & United Kingdom & $2,183,277$ & Brazil & $3,868,813$ \\
\hline 8 & France & $2,154,399$ & United Kingdom & $3,360,442$ \\
\hline 9 & Brazil & $2,138,888$ & France & $3,214,921$ \\
\hline 10 & Italy & $1,767,120$ & Mexico & $2,838,722$ \\
\hline
\end{tabular}

Source: Facts about China: ECONOMY \& GDP 2011-2012, http://www.china-mike.com/facts-aboutchina/economy-investment-business-statistics/.

The integration of China into the world trade system may have increase aggregate welfare in the rest of the world by $0.4 \%$ but factor incomes in individual sectors may fall or rise by more than $5 \%{ }^{71}$. Dealing with relative wage pressures and needs for structural adjustment due to rising trade integration will thus be important. The benefits from trade liberalization are transmitted through several channels like shifting production from low to high locations, relocation of factors of production towards sectors and firms with high productivity and rising incomes due to an increase in market size that supports more specialization, faster technology diffusion and stronger incentives to invest in "non-rival" assets ${ }^{72}$.

China's growth is good for the world economy and for the European Union and USA and also for TTIP project with significant terms of trade gains being experienced in its trading partners, reduction in poverty and increases in living standards. Chinese economic growth has been good at first for Chinese with massive reductions in poverty and rising living standards. Moreover, China is now a very large regional power and the preceding discussion has provided evidence that it has a very large growth effect on its neighboring trade partners. If China continues its path of stable growth there is every reason to export continued and expanded benefits for its trade partners also like EU and USA. It must be emphasized that the Chinese model is not about to overtake the world but its success indicates that multiple versions of modernity will be vying with each other in their

\footnotetext{
${ }^{71}$ Braconier H., Nicoletti G., Westmore B., Policy Challenges for the Next 50 Years, OECD Economic Policy Paper, No. 9 (Authorised for publication by Jean-Luc Schneidr, Deputy Director, Policy Studies Branch, Economic Department OECD, Better Policies for Better Lives, July 2014.)

${ }^{72}$ Ibid.
} 


\section{TRANSATLANTIC COOPERATION REGARDING 549}

marketplace of ideas ${ }^{73}$.

China may continue to specialise in electronics and increasingly in services, while manufacturing may continue in the framework of the relations with the OECD and also with the European Union countries and USA. With or without further trade agreements because of TTIP, services will be more traded and trade policies will have to adjust to changes in the organisation of global value change ${ }^{74}$. It must be emphasized that the EU and USA in the framework of TTIP have a strong record of international cooperation and of providing development support and assistance to many parts of the world. This includes promotion of human rights in all external actions.

\section{RESULTS AND FINDINGS}

Transatlantic reforms could set a powerful precedent for initiatives like the TTIP in other regions and in the World Trade Organization. Contrary to concerns that another broad-based bilateral accord would further dampen prospects for an international trade agreement, it believes that a TTIP, properly constructed, could help break the deadlock in the WTO's Doha Round negotiations. In particular, TTIP provisions could become a template for the stalled global trade talks in several difficult areas, from agriculture to cross-border rules on services, investment and regulations. A comprehensive TTIP has important implications for both bilateral trade and the world trading system. If successful, it could strengthen transatlantic economic relations while also spurring trade reforms that both sides could jointly put forward to reinvigorate flagging multilateral trade negotiations.

Ideally, the best way to address problems arising from regulatory divergence would be on a multilateral basis. In advance of that eventual goal, however, a US-EU regulatory cooperation process could lay the foundation for a broader effort in the future. If the USA and the EU can resolve some of the easier issues-like mundane problems such as different regulations for automobile headlights-perhaps that can serve as a building block for a broader multilateral effort also for China. Success in this area will be difficult, but the gains are potentially large, and thus an attempt to solve this

\footnotetext{
${ }^{73}$ Kupchan Ch. A., Parsing TTIP's Geopolitical Implications in THE GEOPOLITICS OF TTIP REPOSITIONING THE TRANSATLANTIC RELATIONSHIP FOR CHANGING WORLD (D.S. Hamilton, ed., Centre for Transatlantic Relations, Paul H. Nitze School of Advanced International Studies, John Hopkins University, Washington DC. 2014).

${ }^{74}$ Braconier H., Nicoletti G., Westmore B., Policy Challenges for the Next 50 Years, OECD Economic Policy Paper, No. 9 (Authorised for publication by Jean-Luc Schneidr, Deputy Director, Policy Studies Branch, Economic Department OECD, Better Policies for Better Lives, July 2014.)
} 
long-standing problem is worth the effort.

The negotiations for the Trans-Pacific Partnership agreement and the Transatlantic Trade and Investment Partnership could provide the basis for developing new WTO Plus system. Negotiations for the TPP and the TTIP could be vehicles for establishing a WTO Plus system. These agreements establish effective rules regarding neo mercantilist practices and eschew special interest provisions. Such a WTO Plus system would both open markets for countries willing to accept strengthened trade rules and put pressure on non participating countries to further open their markets and adopt similar rules in a future multilateral trade round in the framework of the WTO.

It must be emphasized that in the new WTO, the diverse membership must find common ground on new areas of negotiation. The process of these negotiations must begin with domestic adjustment and development trade policies, and continue by harnessing all the available incentives, from TTIP to aid-for-trade, and by new forms of cooperation between developed, developing, and emerging countries like China. The economic incentives for multilateral trade liberalization remain strong, and the new international economy of more broadly shared economic power represents a major victory for its success in the framework of the WTO multilateral tarde system, but the power in the WTO has symbolic character.

With or without further trade agreements like TTIP, services will be more traded and trade policies will have to adjust to changes in the organisation of global value change. The question raised is whether the West also USA and EU will see China's rise as an opportunity for cooperation or for conflict. Economic growth is generally more preferable in China to military and extensive expansion. With new investments, a country can transform its position through industrial expansion at home and sustain it through international trade. China is especially sensitive to the advantages of intensive growth and will not wish to disrupt essential economic arrangements that have been crucial to her success.

The former two effects include mostly static from international trade in goods, services and factors of production, while the latter entails dynamic growth effects. Significant static and dynamic efficiency gains, especially for China, could be reaped through further multilateral trade liberalization while global welfare gains from regional agreements like TTIP are much more limited due to trade diversion. Trade diversion leads to discrimination against third countries. As a result, there might arise a feeling of unfair treatment culminating in anti-liberalism tendencies or even an aversion to the Western economic order. While fostering multilateral trade liberalisation 


\section{TRANSATLANTIC COOPERATION REGARDING 551}

has proved difficult in the recent past and regional arrangements have been frequent, the former should remain priority due these larger benefits and despite the practical challenges of seeing through such reforms in a multipolar world. These results are based on the partial multilateral trade liberalization scenario based on multilateral cuts in tariffs $(50 \%)$ and transaction cost $(25 \%)$ relative to baseline.

It must be emphasized that United States and EU deepen their ties to each other, must keep their eyes on the prize and work with emerging powers, democracies and non-democracies alike, to fashion a new rule based system for the twenty-first century. The challenge ahead is helping to extend that accomplishment to the rest of the world. TTIP initiative comes at the right time. Now benefits of doing business with the emerging markets have declined and transaction costs have increased. The financial crisis has led to high unemployment rates and high public debts on both sides of the Atlantic. New impulses for growth are needed to improve prospects for employment, growth and welfare.

TTIP could spur growth, translate into millions of new jobs in the United States and Europe, and improve both earnings and competitiveness for many companies, particularly small and medium-sized enterprises on both sides of Atlantic. However the benefits would not be only to the United States and the EU. They would spread out worldwide. TTIP is open and encourages third countries to join. As a result, the TTIP would become the core of a new global trading system where the rule setters are once again the most advanced economies. In the long run, all countries could benefit from more prosperity in the transatlantic area. That is why TTIP should become a success, not a failure.

\section{CONCLUSION}

The need for firms to organize their supply chains across different countries has led to a demand for regional agreements like TTIP that cover more than preferential tariffs. The harmonization of standards and rules on investment, intellectual property and services has become a standard part of new trade agreements. The differences among firms involved in trade are also important for the future development. The picture that arises from the trade is that even if many firms are indirectly involved in trade-related activities, only relatively few are exporting or importing and these firms tend to be larger and more productive than others. Such firms also have a role in technology advancement and the diffusion of know how through supply chains. 
Current trends in world economy and global politics provide evidence that emerging markets like China have now arrived to the world economy at last, bringing with it new patterns of uneven development, inequality and injustice. Its newly confident elites, now fully engaged in global circuits of trade, investment and finance, and in global governance too, appear to have left behind their previous role. It is clear that the emerging economies like China, has suffered less and recovered more quickly. In addition, it now seems that the patterns of political do not impact in the sense of immediate crisis measures but of long-term very big shifts may be equally significant and unexpected.

The trade policy plays a key role in the maintenance of both economic and political liberalization. The prominence of rent seeking in a country can have far-reaching implication for its economic development. Especially in transitional countries, rent seeking takes scarce resource out of productive areas in the economy, using them to promote and perpetuate further rents. United States and the EU are each other's most important trade partners. Both regions have similar cost and production structures, similar levels in economic development, deep political relations and strong cultural similarities. Therefore the reduction of trade frictions could help to reallocate more efficiency production factors especially capital firms and their production sites and to make use of comparative advantages, economies of scale and joint research activities to develop new technologies. However it should be stressed that free trade in itself is not responsible for economic growth, but more significant are the determining macroeconomic stability and increasing investment.

If TTIP succeeds, the partners would intend to follow with effort to conform all these agreements in trade coverage and rules of origin, in particular to reduce distortions and generalize the benefits. A TTIP, complementing NATO and the other longstanding political and alliance links between USA and EU, will be the foundation for strengthened "Atlantic Basin" that can confidently turn to the Pacific, the Middle East or other challenges in the decades ahead. That will be the strategic significance of TTIP. It is important to underline that no two group of nations have closer ongoing collaboration on security, intelligence and political matters that the NATO partners of Europe and North America. The United States and Europe are able to take decisive steps forward at a time when solidarity between them is greatly needed to revitalize their own economies, to reinforce their cooperation and to play a collective leadership role in promoting their values on the global world. 